\title{
REVIEW
}

\section{Human dimensions of bycatch reduction technology: current assumptions and directions for future research}

\author{
Lisa M. Campbell* ${ }^{*}$ Myriah L. Cornwell \\ Nicholas School of the Environment, Duke University,Marine Lab, 135 Duke Marine Lab Road, \\ Beaufort, North Carolina 28516, USA
}

\begin{abstract}
Bycatch reduction technology (BRT) modifies fishing gear to increase selectivity and avoid capture of non-target species, or to facilitate their non-lethal release. As a solution to fisheriesrelated mortality of non-target species, BRT is an attractive option; effectively implemented, BRT presents a technical 'fix' that can reduce pressure for politically contentious and economically detrimental interventions, such as fisheries closures. While a number of factors might contribute to effective implementation, our review of BRT literature finds that research has focused on technical design and experimental performance of individual technologies. In contrast, and with a few notable exceptions, research on the human and institutional context of BRT, and more specifically on how fishers respond to BRT, is limited. This is not to say that fisher attitudes are ignored or overlooked, but that incentives for fisher uptake of BRT are usually assumed rather than assessed or demonstrated. Three assumptions about fisher incentives dominate: (1) economic incentives will generate acceptance of BRT; (2) enforcement will generate compliance with BRT; and (3) 'participation' by fishers will increase acceptance and compliance, and overall support for BRT. In this paper, we explore evidence for and against these assumptions and situate our analysis in the wider social science literature on fisheries. Our goal is to highlight the need and suggest focal areas for further research.
\end{abstract}

KEY WORDS: Bycatch $\cdot$ Technology $\cdot$ Fisheries $\cdot$ Charismatic species $\cdot$ Social science $\cdot$ Stakeholder participation

\section{INTRODUCTION}

In this paper, we present results of a literature review that examines efforts to reduce some of the ecological impacts of fisheries through design and implementation of bycatch reduction technology (BRT) in fishing gear. As social scientists interested in fisheries, but with no primary research experience with BRT, we are interested in learning under what conditions fishers are encouraged or discouraged from implementing BRT. Fisher cooperation is increasingly seen as critical to improving fisheries management in general, particularly in light of widespread failures of states to manage fisheries thorough predominantly command and control approaches (Pinkerton 1989, Nielsen \& Vedsmand 1999, Jentoft 2000, Singleton 2000, Berkes 2003). While most research has focused on fisher cooperation with and attitudes towards overall management approaches - for example Individual Transferable Quotas (McCay et al. 1998) or co-management (Wilson \& McCay 1998) - there is no reason to expect that the introduction and uptake of BRT will somehow be less dependent on fishers' willingness to cooperate. The impacts of technical modifications to fishing gear will be limited if fishers lack incentives for implementing BRTs or cannot be compelled to do so.

Over the past several years, a 'degradation narrative' (Robbins 2004) of fisheries decline (and hypothesized 
collapse) has emerged in some fisheries literature (e.g. Worm et al. 2006). Regardless of the veracity of such claims, the crisis is generally described as one of overfishing, and linked to over-capitalization of and subsidies to fishing fleets, and to the open access nature of most fish stocks (Pauly et al. 2002). Fisheries by-catch, or 'that portion of the capture that is discarded at sea dead (or injured to an extent that death is the most likely outcome) because it has little or no economic value or because its retention is prohibited by law' (Hall 1996, p. 322), is also of increasing global concern. To some extent, the bycatch problem is linked to general problems in fisheries. For example, bycatch of juvenile fish can contribute to overall long-term declines in commercially valuable fish stocks. Further, although size and capability of fleets have increased through industrialization, selectivity in gear has not (Hall \& Mainprize 2005). Escalating levels of bycatch emerged with the rapid development of fishing technologies and the expansion of commercial fishing (Hall \& Mainprize 2005). A United Nations (UN) report published in 2005 estimated that fish discards account for about $8 \%$ of the world's catch, or approximately 7.3 million $t$, although earlier estimates using different methods produced much higher percentages and discard amounts (Kelleher 2005).

Regardless of the exact quantity of bycatch, its existence has become particularly problematic for fisheries when endangered or charismatic species of conservation interest, like sea turtles and marine mammals, are the non-target species at stake. In such cases, the bycatch problem can resemble the larger crisis in fisheries when decline in the bycaught species is a product of fishing (Kennelly \& Broadhurst 2002). For example, when the US government mandated the use of turtle excluder devices (TEDs) in shrimp trawls fishing US waters, it was to address the impacts of bycatchrelated sea turtle mortality on overall population status; bycatch was deemed the number one threat to sea turtle survival (National Research Council 1990). Similarly, public uproar over the mortality of dolphins in the Eastern Pacific tuna fishery, credited with the passage of the US Marine Mammal Protection Act (MMPA) of 1972 (Hall \& Mainprize 2005), was linked to concerns about the impacts of bycatch-induced mortality on dolphin population status (Hall et al. 2000). These examples mirror the overall crisis of decline, though neither sea turtles nor dolphins were targeted directly. The case of charismatic species differs from the general fisheries crisis in that concerns about bycatch-related mortality can often be decoupled from population status; for some sectors of the public, concern extends to the mortality of individual animals, whether or not the population in question is decreasing, stable, or increasing. There are obviously cases where bycatch remains a serious threat to some charismatic species, the case of Pacific leatherback sea turtles being one example (Spotila et al. 2000), but concern about bycatch of charismatic animals will likely remain even if the larger fisheries crisis is addressed.

Fisheries management has evolved over the past several decades to devote considerable attention to preventing bycatch of marine mammals, sea turtles, and sea birds (Hall et al. 2000), particularly in the US. Charismatic marine animals present unique challenges for fisher uptake of BRT because of their conservation value rather than their commercial value. While some fishers might see the utility of reducing bycatch of juveniles of a commercially valuable species, they may be less convinced of the need to reduce bycatch of species that lack commercial value, especially in cases where they do not believe such animals to be threatened. Fishers may not share the perception that bycatch of such species is problematic (Moberg \& Dyer 1994, Tucker et al. 1997) or may more generally resent resources spent on their conservation (Santora 2003, Silver \& Campbell 2005). Technologies designed to reduce bycatch of charismatic species may increase bycatch of other species (Hall 1998, Hall et al. 2000, Hall \& Mainprize 2005), and when protection measures for charismatic species are not internationally shared, fishers from nations adopting such measures may be at a competitive disadvantage (Hall 1998, Bache 2001). Due to the unique challenges associated with reducing bycatch of charismatic species, and because of the substantial investments made by government and researchers towards addressing this type of bycatch, particularly in the US, we focus our review on BRTs directed at these animals.

In contrast to the overall fisheries crisis, bycatch is, on the surface at least, a less intractable problem and is particularly amenable to technological intervention (or 'fixes') via gear modification to increase selectivity. Gear modification is not the only solution to bycatch problems, but it is a popular one because it avoids more politically and economically costly decisions; in some instances, fishers themselves have advocated the adoption of BRT as a means to stave off fishery closures (Bache 2001). Other options for reducing bycatch include spatial and temporal fisheries closures where and when bycatch levels are high (Bache 2000, Gilman 2001) and establishing caps and quotas for bycatch levels (Diamond 2004). In the case of charismatic species, fishers may resist the former, and the public and environmentalists the latter (although both of these measures are used in the US, e.g. see Santora 2003). Focusing on BRT also creates a 'new' research industry, with energies and financing directed to creative endeavors (such as designing and testing gear modifications) rather than monitoring, enforcing, and penal- 
izing fishers. Thus, BRT theoretically can contribute to improved relations between fishers and fisheries managers, especially if, as much of the literature recommends (see 'Results; Assumption 3'), fishers are involved in the design and testing of BRT from the outset.

While the search for a technological fix to the bycatch problem stems at least in part from the social, political, and economic costs of other approaches, technological fixes do not occur in social, political, and economic vacuums. If the general literature on fisheries is indicative, the human and institutional contexts in which BRT is introduced will be critical to success or failure. Nevertheless, our review finds that most BRT studies focus on technical design and experimental performance of individual technologies. With a few notable exceptions (Margavio et al. 1993, Moberg \& Dyer 1994, Margavio \& Forsyth 1996, Jenkins 2006, Hall et al. 2007, Jenkins 2007), the human and institutional contexts of BRT, and more specifically how, when and why fishers do or do not employ BRT, are seldom addressed as research questions. This is not to say that fisher attitudes are ignored or overlooked, but that incentives for fisher uptake of BRT are usually assumed rather than demonstrated. Three assumptions dominate: (1) economic incentives will generate acceptance of BRT; (2) enforcement will generate compliance with BRT; and (3) 'participation' by fishers will increase both acceptance and compliance, and overall support for BRT.

In this paper, we trace these assumptions in the relevant bycatch literature (described in 'Methods'), explore evidence for and against them and situate our analysis in the wider social science literature on fisheries. In doing so, we do not intend to critique the existing literature on BRT for failing to research whether or not assumptions hold true; such research is beyond the scope of many of the reviewed papers. Rather, we suggest that the assumptions made by BRT researchers, many of whom have long and direct experience working on these issues, combined with what we know from fisheries social science more generally, provide an indication of the kinds of questions that can inform further research. Given the explanatory power afforded to some of the existing assumptions (e.g. 'Successful implementation depended on continued communication, education, and outreach through the implementation stages' (Cox et al. 2007, p. 1161), their further investigation is warranted.

\section{METHODS}

Our review focuses on papers concerned with technical innovations that modify or replace gear (for example, changes to net design rather than operational changes such as altered soak times) and that include reference to BRT uptake by fishers, whether or not uptake is the primary focus of analysis or a secondary issue. We specifically focus on BRT relating to marine mega-fauna for the reasons given earlier, and draw on papers published in peer-reviewed journals on marine policy, conservation, fisheries, coastal management, and marine technology. We categorize the reviewed literature under 3 headings: general assessments of bycatch, comparative case studies of fishery gears, and studies of bycatch in specific fisheries (Table 1). In conducting our analysis, we noted and extracted all references to factors assumed to influence BRT uptake. We interpreted references to the uptake of BRT as assumptions when no data or analyses were provided. When all statements were obtained, we coded the references to uptake and grouped them

Table 1. Type of study and assumptions found in reviewed papers

\begin{tabular}{|c|c|c|c|}
\hline $\begin{array}{l}\text { Type } \\
\text { Source }\end{array}$ & $\begin{array}{c}\text { Economic } \\
\text { assumptions }\end{array}$ & $\begin{array}{l}\text { Enforcement } \\
\text { assumptions }\end{array}$ & $\begin{array}{c}\text { Participation } \\
\text { assumptions }\end{array}$ \\
\hline \multicolumn{4}{|l|}{ General bycatch } \\
\hline Bache (2003) & $\mathrm{X}$ & $\mathrm{X}$ & \\
\hline Bache (2000) & $\mathrm{X}$ & $\mathrm{X}$ & \\
\hline Hall (1996) & $\mathrm{X}$ & & \\
\hline Hall \& Mainprize (2005) & $\mathrm{X}$ & $\mathrm{X}$ & $\mathrm{X}$ \\
\hline Harrington et al. (2005) & $\mathrm{X}$ & & \\
\hline Kennelly \& Broadhurst (2002) & & & $\mathrm{X}$ \\
\hline \multicolumn{4}{|l|}{ Comparative } \\
\hline Cox et al. (2007) & $\mathrm{X}$ & $\mathrm{X}$ & $\mathrm{X}$ \\
\hline Gilman et al. (2003) & $\mathrm{X}$ & $\mathrm{X}$ & $\mathrm{X}$ \\
\hline Gilman et al. (2006b) & $\mathrm{X}$ & $\mathrm{X}$ & $\mathrm{X}$ \\
\hline Watson (2007) & & $\mathrm{X}$ & $\mathrm{X}$ \\
\hline \multicolumn{4}{|l|}{ Fishery specific } \\
\hline Brewer et al. (1998) & $\mathrm{X}$ & & \\
\hline Broadhurst (2000) & $\mathrm{X}$ & & $\mathrm{X}$ \\
\hline Gilman et al. (2006a) & $\mathrm{X}$ & & \\
\hline Gilman et al. (2005) & $\mathrm{X}$ & $\mathrm{X}$ & $\mathrm{X}$ \\
\hline Gilman (2001) & $\mathrm{X}$ & $\mathrm{X}$ & $\mathrm{X}$ \\
\hline Kennelly (1999) & & & $\mathrm{X}$ \\
\hline Kennelly (1995) & & & $\mathrm{X}$ \\
\hline Melvin et al. (1999) & & & $\mathrm{X}$ \\
\hline Robbins et al. (1999) & & & $\mathrm{X}$ \\
\hline Tucker et al. (1997) & $\mathrm{X}$ & & $\mathrm{X}$ \\
\hline Watson (2006) & $\mathrm{X}$ & & \\
\hline
\end{tabular}


together under the 3 emerging categories of assumptions outlined above (following Glaser \& Strauss 1967).

\section{RESULTS}

Table 1 shows articles reviewed and their grouping according to the type of study and to the categories of assumptions found therein.

\section{Assumption 1. Economic incentives generate acceptance}

Much of the literature on BRT uptake assumes that fishers will respond favorably to economic incentives (Bache 2003, Gilman et al. 2003, 2005, 2006b, Hall \& Mainprize 2005, Harrington et al. 2005, Cox et al. 2007), especially when combined with enforcement (see next section). Economic incentives are linked to the increased efficiency of fishing effort and higher catch values that result from BRT use (as opposed to direct subsidies for BRT use). Increased efficiency and higher catch values are believe to arise through the following factors: less time spent sorting unwanted catch (Brewer et al. 1998, Broadhurst 2000, Fonseca et al. 2005); less damage to nets and catch from trapped megafauna (Brewer et al. 1998, Bache 2003); higher catch values because net space and bait are not taken by non-target catch (Brewer et al. 1998, Bache 2000, Broadhurst 2000, Gilman 2001, Gilman et al. 2003, Fonseca et al. 2005, Hall \& Mainprize 2005, Cox et al. 2007); lower fuel costs due to reduced net drag (Margavio et al. 1993, Moberg \& Dyer 1994, Bache 2000, Broadhurst 2000); decreased overall number of trips needed since vessels will not go over bycatch trip limits and more target catch has been captured (Brewer et al. 1998, Broadhurst 2000, Hall \& Mainprize 2005, Gilman et al. 2006b); uninterrupted access to fishing areas due to minimized bycatch (Gilman et al. 2006b, Cox et al. 2007); and potential for marketing of ecofriendly seafood to consumers (Bache 2000, Gilman et al. 2005). Some distinct economic incentives are related to enforcement, e.g. fear of fisheries closure or lost access to markets, and these are treated in the 'Assumption 2' section.

Although these incentives may be influential among fishers, there are very few data on or analysis of economic incentives; this points to 3 areas for further research. First, there is a need to quantify economic costs and benefits of BRT to fishers more thoroughly. In all 3 types of studies, economic benefits are usually assumed rather than calculated. For example, in their overview of bycatch in the US, Harrington et al. (2005, p. 358) suggest 'More selective gear can mean highervalue landings for fishermen at potentially lower costs,' but provide no data to support this conclusion. In their assessment of a specific seabird BRT in the Hawaiian longline tuna fishery, Gilman et al. (2003, p. 987) observe that 'the longline industry is expected to respond most strongly to economic incentives and disincentives,' but do not elaborate on what these incentives might be and how they might function within the fishery. Gilman et al. (2006b) make similar assumptions about the balance of economic costs and benefits in their study of a fleet communication program to abate bycatch. They claim that the 'Available information from three case studies of fleet communications programs indicates that economic benefits likely substantially outweigh costs' (Gilman et al. 2006b, p. 365), but concede that 'there has been no formal assessment of the economic benefits and costs from instituting the fleet communication program' (Gilman et al. 2006b). Even when incentives are specified, those incentives need to be considered in the overall economics of the fishery. For example, Cox et al. (2007, p. 1160) argue that savings incurred through reduced loss of bait and hooks to seabirds will help provide incentives for BRT uptake, since 'Bait and hooks lost to seabirds are not available to catch fish.' Without an understanding of the overall economics of the fishery, the importance of bait and hook loss to seabirds is difficult to assess. Research evaluating actual economic costs and benefits will assist in assessing the potential incentives for fishers to use BRT.

Second, research should be directed to assessing costs and benefits of BRT under 'real' conditions. Many of the economic benefits of adopting BRT are projected to arise from the efficient performance of the technology itself, with estimates of increased efficiency made during experimental trials. Problems arise for BRT uptake when experimental efficiencies do not materialize in practice (Cox et al. 2007, Hall et al. 2007). For example, when TEDs were introduced in the Gulf of Mexico shrimp fishery, some of the most common complaints by fishers were that TEDs resulted in significant shrimp loss, malfunctioned and caused extra drag on trawlers, were cumbersome and difficult to operate, and were improperly installed by National Marine Fisheries Service (NMFS) officials on some trawling vessels (Margavio \& Forsyth 1996). Overall, Gulf of Mexico shrimp fishers contested the scientific and government claims about the efficiency of TEDs, citing the poor performance of the devices under commercial conditions (Moberg \& Dyer 1994). Rather than provide incentives for use through increased efficiency, TED performance initially produced economic disincentives for TED use. Similarly, acoustic pingers to reduce cetacean bycatch in gill-nets have proven successful in experiments (Kraus et al. 1997), but their overall effectiveness in commercial gill-net fisheries remains a con- 
cern due to potential habituation of cetaceans to pingers and their impacts on the distribution of herring (Dawson et al. 1998). In addition to concerns about their baseline efficiency, pingers must be properly maintained, an expense for fishers, and their malfunction can reduce their effectiveness (Dawson et al. 1998, Bache 2003, Cox et al. 2007). Costs may also rise due to increased bycatch of other species; some studies (Hall 1998, Hall \& Mainprize 2005) address the rise in other types of bycatch, but the potential costs of this outcome remain unexamined. Given these concerns, evaluations of BRT under commercial conditions should complement the current studies on experimental performance of BRT.

Third, assessment of economic incentives should be accompanied by assessment of the social and cultural context of BRT. The exclusive focus on economic incentives for BRT underestimates the importance of this context and of the broader economic context in which BRTs are introduced (Margavio et al. 1993, Jenkins 2006, Hall et al. 2007); these 'other' issues may help to explain why potential economics benefits do not always translate into uptake (e.g. Hall \& Mainprize 2005). For example, fisher resistance to TEDs in the Gulf of Mexico shrimp fishery, and the related conflict between fishers and NMFS, has been linked to a variety of non-economic factors and to the broader economic context. In terms of non-economic factors, Margavio \& Forsyth (1996) describe how in the USA resistance of Louisiana fishers to TEDs can be seen as a defense of traditional cultural practices, fear of eroding independence, and anger at the marginalization of shrimping in the face of competing economic activities. Economically, the fishery was suffering from competition from cheap imports from Asia and South America and from farmed shrimp, higher fuel and insurance costs, falling prices, overcapitalization of the fishery, and crowding within the fishery (Margavio et al. 1993, Moberg \& Dyer 1994, Tucker et al. 1997). This overall economic context, rather than the costs and benefits of TEDs specifically, proved an important component of the conflict.

The emphasis on economic incentives in BRT research reflects a dominant view in the wider literature on fishers that portrays them as economically rational individuals, seeking only to maximize profits and/or minimize risks. Fishers may behave in ways that conform to such neoclassical economic expectations, but economic rationality is not the only influence on their behavior (Maurstad 2000, St Martin 2001, 2005), as the case of TEDs in Louisiana demonstrates (Margavio \& Forsyth 1996). Research on social and cultural dynamics and context could greatly improve our understanding of fisher responses to BRT.
An important element of such dynamics and context is the relationship between fishers and management agencies. Several studies of the TEDs case (Margavio et al. 1993, Moberg \& Dyer 1994, Margavio \& Forsyth 1996, Jenkins 2006) consider how different stakeholders became embroiled in a fierce battle over BRT. By the time TED regulations went into effect in the Gulf of Mexico, fisher hostility to TEDs was high and resulted in wide-spread fisher resistance that authorities struggled to overcome (Moberg \& Dyer 1994). Jenkins (2006) contrasts the relationships between fishers on the US East Coast with Sea Grant agents, where the implementation of TEDs went much more smoothly, and relationships between fishers and NMFS agents in the Gulf of Mexico as a means of understanding how fisher-agent relationships impact BRT uptake. Such relationships impact fisher assessment of potential economic benefits and, as will be discussed below, the possibilities for enforcement.

\section{Assumption 2. Given enough resources, enforcement will compel BRT uptake}

Within the BRT literature, there are 2 central views of the role of enforcement in improving BRT uptake. Studies often support the power of enforcement to compel technology adoption in theory (View 1), while lamenting the failures of enforcement in practice (View 2). Both views are supported by assumptions about enforcement rather than data and analysis. In the first view, enforcement ensures compliance (Gilman et al. 2003, 2005, 2006a, Watson 2007). For example, 'If regulations requiring the use of seabird avoidance methods are effectively enforced and carry sufficient economic consequences for non-compliance, broad industry compliance can be achieved' (Gilman et al. 2005, p. 44). From this perspective, enforcement actions create economic incentives different than those described in the previous section. Enforcement is assumed to incentivize fishers to avoid putative action (e.g. avoiding fines or loss of fishing license, gaining privileges) rather than to fish more efficiently. While enforcement-related incentives may work in some fisheries, there has been little attention paid to what kinds of regulations produce economic incentives for compliance and in what ways they function in particular fisheries. For example, Cox et al. (2007, p. 1160) assert that 'The Patagonian toothfish fishery is highly profitable, so the industry is keen to continue fishing and therefore follow license requirements.' This statement points to important questions about the links between profitability, fisher incentives, and enforcement capacity. Under what circumstances does the scenario described by Cox et 
al. (2007) play out? High profitability does not in itself provide incentives for fishers to follow rules. If fines are too low, profits might overwhelm these and encourage risk taking by fishers. On the other hand, if some profits are redirected to enforcement, profitable industries may be better monitored. In order for enforcement to produce these theorized incentives, management agencies must have the capacity to carry out the necessary enforcement. The point here is that enforcement-compliance relationships warrant further attention.

The second assumption of enforcement is that, while it might ensure compliance in an ideal world, it often fails in practice because agencies do not have the resources to effectively enforce BRT regulations, and this leads to compliance failure (Gilman 2001, Bache 2003, Hall \& Mainprize 2005, Gilman et al. 2006a). While there is often a general sentiment that there are not enough resources devoted to enforcement, there has been little research on the specific types of enforcement required or the resources needed to support it. For example, Gilman et al. (2006a, p. 4) assert that 'for longline fisheries that do have provisions to manage bycatch, resources for enforcement tend to be insufficient to ensure compliance.' This raises the question of what level of enforcement would be sufficient, or whether or not particular BRT regulations are, in fact, unenforceable. Watson (2007) argues that improved enforcement contributed to successful uptake of TEDs after the controversy in the Gulf of Mexico, but there is little discussion of how and in what ways enforcement worked. There remains much to be learned about how enforcement processes produce particular outcomes.

One study that does look at enforcement in depth is Jenkins's (2006) study of the TED conflict. Jenkins (2006) found that Texas shrimpers responded to increased fines and threats of catch seizures with increased TED compliance, but not to the point of complete adoption. Rather, shrimpers attempted to 'beat the system' by tying off their TEDs in the water, looking for loopholes in the regulations and simply not employing TEDs until caught without them. This situation created what Jenkins (2006) terms an 'arms race' between enforcement agencies and shrimpers, one that drained agency resources. Jenkins (2006) argues that enforcement can support uptake, but only when the probability and costs of being caught are high, and even then only to a certain point: 'enforcement is not a substitute for nor can it assure true adoption.' Jenkins' work also highlights that the economics of the enforcement-compliance relationship is only one aspect of it. As Margavio et al. (1993), Moberg \& Dyer (1994), Margavio \& Forsyth (1996), and Jenkins (2006) have all made clear, it is critical to evaluate the socio-cultural context, including relations between fishers and management agencies, and how that context influences the possibilities for enforcement.

Existing research also suggests that the success of enforcement is likely to be influenced by the specifics of both the fishery and the gear being regulated. For example, Cox et al. (2007) discuss the problems with TED enforcement, since escape flaps sewn shut can be hard to observe on trawls in the water. Similar issues plague the enforcement of pingers, since the Coast Guard is not equipped to check the functionality of pingers at sea and dockside enforcement is not conducted because some fishers will not attach pingers until they are in the water (Bache 2003). Beyond gear types, other factors can affect the viability of enforcement. Gilman et al. (2003) argue that the enforcement opportunities in Hawaiian longline fisheries are constrained by the extensive range of the fishing grounds. Covering a large expanse of fishing grounds may not be possible for enforcement agencies that have limited resources and are occupied by other duties. While the technicalities of gear and factors such as the geographic specifics of fisheries warrant further consideration, we suggest these are in some ways subsidiary to larger questions of economic, institutional, and socialcultural context. We also note that the attention given to enforcement (its limitations and potential) is likely a reflection of the origins of most BRT studies in the USA and other developed countries (e.g. Australia). Enforcement will face additional challenges in other regions (e.g. the Caribbean, Chakalall et al. 2007).

\section{Assumption 3. Fisher participation ensures support for BRT uptake}

Critiques of enforcement are often accompanied by calls for fisher 'participation' as an alternative means of ensuring BRT compliance, but such calls often reflect a limited conception of what participation might entail. Participation is invoked in 2 main ways. First, participation is often equated with education (Tucker et al. 1997, Kennelly 1999, Broadhurst 2000, Cox et al. 2007, Watson 2007), and this focus assumes that improved fisher 'understanding' of the bycatch problem, the technology itself, or the advantages of using it, will facilitate uptake (Tucker et al. 1997, Robins et al. 1999, Broadhurst 2000, Cox et al. 2007, Watson 2007). For example, Moberg \& Dyer (1994) and Tucker et al. (1997) suggest that part of the problem in the Gulf of Mexico shrimp fishery was that shrimpers did not believe that the fishery was contributing to high sea turtle mortality, and thus did not appreciate the need for TEDs. Hall et al. (2007) demonstrate that opening a dialogue with fishers 
about threats can help convince fishers to participate in BRT design and implementation, even if they do not feel they pose a threat to the species caught as bycatch. Second, participation is invoked as a means to improve BRT technology. Since fishers have expertise with fishing gears, BRT development should utilize fisher knowledge in the creation of viable technology. Advocates of this bottom-up approach argue that such partnerships not only create better technology, but increase uptake and compliance through cultivating a sense of ownership among fishers (Kennelly 1995, 1999, Kennelly \& Broadhurst 1996, Melvin et al. 1999, Gilman et al. 2003, 2005, 2006a,b, Watson 2007). In the US, the most widely adopted BRTs are those produced and modified by fishers (Jenkins 2006), and in Australia the most effective implementation of a BRT was in a fishery where fishers had instigated efforts to reduce bycatch (Kennelly 1999).

The literature on participation suggests both ways in which the treatment of the issue in the BRT literature is problematic and ways in which managers and researchers might think more productively about it. For example, equating participation with education may (unintentionally) hinder BRT design and uptake for several reasons. First, at a fundamental level, fishers may not value charismatic animals in the same way that the public, environmental groups, and some resource management agencies (and/or their mandates) do, and any values fishers do attach to these animals may be overridden by resentment regarding the time and energy spent on their management (Campbell 2000, Santora 2003, Silver \& Campbell 2005). In such cases, setting out to educate fishers on their contributions to declining populations (and thus spending more time and energy on charismatic species) may increase fisher resentment.

Second, scientists and managers sometimes assume that experimental trial or gear demonstrations will be sufficient to educate fishers regarding BRT performance (Hall \& Mainprize 2005). As discussed above, results of experimental trials are often not replicated under commercial conditions (Margavio et al. 1993, Moberg \& Dyer 1994, Tucker et al. 1997), and trials may not evaluate the factors that influence fisher willingness to adopt BRT. For example, cumbersome and elaborate gear may impose burdens on fishers (Hall et al. 2000, Hall \& Mainprize 2005, Cox et al. 2007) that they may not be willing to bear.

Finally, the argument that fishers do not support BRTs because they do not understand them is too simplistic. Santora (2003) found fishers particularly resentful of the way scientists discount fisher knowledge, and such social identification with scientific institutions may strongly influence fisher 'understanding' of science: 'perceptions of science cannot be divorced from
... perceptions of the complex web of social and institutional relations in which it is embedded' (McKechnie 1996, p. 129). Wynne (1996) outlines a number of criteria fishers might use to evaluate scientific information, including: whether or not such knowledge works, whether scientific claims attend to other available knowledge; the institutional affiliations of scientists, and whether or not scientists respond to criticism. Returning to the TED example, fisher distrust of scientists rather than fisher knowledge of TEDs (which were based on fisher technology) shaped fisher resistance.

'Participation' in management by resource users has been widely promoted over the past several decades (Western \& Wright 1994, Pretty 1995, Campbell \& Vainio-Mattila 2003), and fisheries are no exception (McCay \& Jentoft 1996, Berkes 2003, Silver \& Campbell 2005, Abbott et al. 2007). While participation is a widely accepted concept, it continues to be problematic, so the BRT literature is by no means exceptional. It is not so much the idea of participation that is contested, but what participation actually entails and to what ends (Campbell 2000, Campbell \& Vainio-Mattila 2003, Hayward et al. 2004). The varying interpretations of participation lead to high potential for misunderstanding; without a shared understanding of the intent of a participatory process (e.g. to educate versus empower fishers), fishers can react negatively with reactions including distrust, anger, and confusion (Wilson \& McCay 1998). Participation is also costly for fishers, who give their time, most often freely (cf. Cooke \& Kothari 2001); they are more likely to be willing to participate in activities which they see as beneficial to themselves and reflect their interests and concerns.

While numerous studies on BRT cite the important role that fisher participation in the design of BRT can play in ensuring compliance, little is said about how fisher participation will work and in what ways it will promote compliance or what the participatory process entails. Most of the studies reviewed for this paper adopt views of participation as a means to an end (to ensure fisher buy-in and compliance) rather than participation as an end in itself, e.g. a process that might empower fishers to develop BRT solutions and create better working relationships with regulatory agencies. Several studies (Kennelly \& Broadhurst 1996, Kennelly 1999, Hall \& Mainprize 2005) do note the importance of generating trust between fishers, scientists, and government officials participating in developing BRT, but say little about how such trust can be generated. Overall, the emphasis is on the benefits of participation for BRT uptake without discussion of what participation means.

Hall et al. (2007) provide a notable exception in their review of fisher participation in the implementation of BRT in 7 case studies from fisheries around the world. 
Hall et al. (2007) consider participatory processes and provide specific advice about fisher participation including: respecting fishing as a livelihood; keeping an open dialogue with fishers about BRT performance and responding to feedback; and acknowledging the risk fishers take by working on BRT. The case studies also illustrate the importance of recognizing and engaging with the social networks of fishers and understanding the broader social and political context of fisheries, which is also the context in which participation occurs. It is the absence of these kinds of specifics that is most problematic in the literature that invokes participation. Most studies say little about how fishers were engaged, the development of the participatory program, and what aspects of it produced particular outcomes. Further research is needed to fully examine the process of participation and its impacts on uptake.

\section{CONCLUSIONS}

In our review of the BRT literature, we find the majority of studies are focused on technical design and experimental performance of gear. A subset of these studies, including those reviewed in this paper, go beyond technology to consider how and why fishers respond to BRT in particular ways, but only a small number take on such issues as research questions. We offer this summary not as a critique of studies that make assumptions about fisher incentives; rather, we use these assumptions, supplemented with existing social science research on fisheries more generally, to outline areas for further research on the human and institutional context of BRT uptake. We argue that such research will be vital to realizing the potential of BRT to resolve bycatch problems, and this is likely particularly true in the case of charismatic species that lack economic value for fishers and where values attached to such animals often vary greatly among stakeholders.

In arguing for more research on the human and institutional aspects, however, we are not suggesting that such studies replace those on technical design and performance. Just as good technology can fail when introduced into a poor human or institutional context, poorly designed technology will not succeed regardless of how positive the overall context. Clearly, both areas of research are important, and we advocate a more holistic approach to BRT, one that engages social scientists as research collaborators. Social scientists, working alone or in collaboration with fisheries scientists and managers, have contributed greatly to our understanding of other aspects of fisheries management, often using detailed case studies to theorize more generally about particular issues, for example, co-management (Pinkerton 1989, Jentoft \& McCay 1995, Berkes 2003), social organization of fishers (Acheson 1988, 2003, St. Martin 2001, 2005), and fisher responses to marine protected areas (Fiske 1992, Badalamenti et al. 2000, Jones 2006). The few social science studies related to BRT that we have reviewed here suggest there is much that social scientists can contribute to understanding, theorizing, and potentially improving the practice of BRT introduction and its uptake by fishers.

Acknowledgements. We are grateful to Noëlle Boucquey, Noella Gray, Matthew Godfrey, Bethany Haalboom, Kiki Jenkins, and 4 anonymous reviewers for providing valuable feedback on this manuscript.

\section{LITERATURE CITED}

Abbott JG, Campbell LM, Hay C, Naesje T, Ndumba A, Purvis J (2007) Rivers as resources, rivers as borders: community versus transboundary management of fisheries in the upper Zambezi River floodplains. Can Geogr 51: 280-302

Acheson J (1988) The lobster gangs of Maine. University Press of New England, Hanover, NH

Acheson J (2003) Capturing the commons: devising institutions to manage the Maine lobster industry. University Press of New England, Lebanon, NH

Bache SJ (2000) International bycatch policy: options for sea turtle conservation. Int J Mar Coast Law 15:333-353

Bache SJ (2001) A primer on take reduction planning under the Marine Mammal Protection Act. Ocean Coast Manag 44:221-239

Bache SJ (2003) Bycatch mitigation tools: selecting fisheries, setting limits, and modifying gear. Ocean Coast Manag 46:103-125

Badalamenti F, Ramos AA, Voultsiadou E, Sánchez Lizaso JL and others (2000) Cultural and socio-economic impacts of Mediterranean marine protected areas. Environ Conserv 27:110-125

Berkes F (2003) Alternatives to conventional management: lessons from small-scale fisheries. Environments 31:5-19

Brewer D, Rawlinson N, Eayrs S, Burridge C (1998) An assessment of bycatch reduction devices in a tropical Australian prawn trawl fishery. Fish Res 36:195-215

Broadhurst MK (2000) Modifications to reduce bycatch in prawn trawls: a review and framework for development. Rev Fish Biol Fish 10:27-60

Campbell LM (2000) Human need in rural developing areas: perceptions of wildlife conservation experts. Can Geogr 44:167-181

Campbell LM, Vainio-Mattila A (2003) Participatory development and community-based conservation: opportunities missed for lessons learned? Hum Ecol 31:417-437

Chakalall B, Mahon R, McConney P, Nurse L, Oderson D (2007) Governance of fisheries and other living marine resources in the Wider Caribbean. Fish Res 87:92-99

Cooke B, Kothari U (eds) (2001) Participation: the new tyranny? Zed Books, New York

> Cox TM, Lewison RL, Zydelis R, Crowder LB, Safina C, Read AJ (2007) Comparing effectiveness of experimental and 
implemented bycatch reduction measures: the ideal and the real. Conserv Biol 21:1155-1164

Dawson SM, Read AJ, Slooten E (1998) Pingers, porpoises and power: uncertainties with using pingers to reduce bycatch of small cetaceans. Biol Conserv 84:141-146

Diamond SL (2004) Bycatch quotas in the Gulf of Mexico shrimp trawl fishery: Can they work? Rev Fish Biol Fish 14: 207-237

Fiske SJ (1992) Sociocultural aspects of establishing marine protected areas. Ocean Coast Manag 17:25-46

Fonseca P, Campos A, Larsen RB, Borges TC, Erzini K (2005) Using a modified Nordmore grid for by-catch reduction in the Portuguese crustacean-trawl fishery. Fish Res 71: 223-239

Gilman E (2001) Integrated management to address the incidental mortality of seabirds in longline fisheries. Aquat Conserv: Mar Freshw Ecosyst 11:391-414

Gilman E, Boggs C, Brothers N (2003) Performance assessment of an underwater setting chute to mitigate seabird bycatch in the Hawaii pelagic longline tuna fishery. Ocean Coast Manag 46:985-1010

Gilman E, Brothers N, Kobayashi DR (2005) Principles and approaches to abate seabird by-catch in longline fisheries. Fish Fish 6:35-49

Gilman E, Zollett E, Beverly S, Nakano H and others (2006a) Reducing sea turtle by-catch in pelagic longline fisheries. Fish Fish 7:2-23

Gilman EL, Dalzell P, Martin S (2006b) Fleet communication to abate fisheries bycatch. Mar Policy 30:360-366

Glaser B, Strauss A (1967) The discovery of grounded theory. Aldine, Chicago, IL

- Hall MA (1996) On bycatches. Rev Fish Biol Fish 6:319-352

Hall MA (1998) An ecological view of the tuna-dolphin problem: impacts and trade-offs. Rev Fish Biol Fish 8:1-34

Hall SJ, Mainprize BM (2005) Managing by-catch and discards: How much progress are we making and how can we do better? Fish Fish 6:134-155

Hall MA, Alverson DL, Metuzals KI (2000) By-catch: problems and solutions. Mar Pollut Bull 41:204-219

Hall M, Nakano H, Clarke S, Thomas S and others (2007) Working with fishers to reduce by-catches. In: Kennelly SJ (ed) By-catch reduction in the world's fisheries. Kluwer Academic Publishers Group, Dordrecht

Harrington JM, Myers RA, Rosenberg AA (2005) Wasted fishery resources: discarded by-catch in the USA. Fish Fish 6: $350-361$

- Hayward C, Simpson L, Wood L (2004) Still left out in the cold: problematising participatory research and development. Sociol Ruralis 44:95-108

Jenkins L (2006) The invention and adoption of conservation technology to successfully reduce bycatch of protected marine species. PhD thesis, Duke University, Durham, NC

> Jenkins L (2007) Bycatch: interactional expertise, dolphins and the US tuna fishery. Stud Hist Philos Sci 38: 698-712

> Jentoft S (2000) The community: a missing link of fisheries management. Mar Policy 24:53-59

Jentoft S, McCay B (1995) User participation in fisheries management: lessons drawn from international experience. Mar Policy 19:227-246

Jones PJS (2006) Collective action problems posed by no-take zones. Mar Policy 30:143-156

Kelleher K (2005) Discards in the world's marine fisheries, an update. FAO Fisheries Technical Paper No. 470. FAO, Rome

Kennelly SJ (1995) The issue of bycatch in Australia's demersal trawl fisheries. Rev Fish Biol Fish 5:213-234
Kennelly SJ (1999) The development and introduction of bycatch reducing technologies in three Australian prawntrawl fisheries. Mar Technol Soc J 33:73-81

Kennelly SJ, Broadhurst MK (1996) Fishermen and scientists solving bycatch problems: examples from Australia and possibilities for the Northeastern United States. In: Solving bycatch: considerations for today and tomorrow, September 25-27, 1995, Seattle, WA. Alaska Sea Grant College Program, Fairbanks, AK, p 121-128

Kennelly SJ, Broadhurst MK (2002) By-catch begone: changes in the philosophy of fishing technology. Fish Fish 3:340-355

> Kraus SD, Read AJ, Solow A, Baldwin K, Spradlin T, Anderson E, Williamson J (1997) Acoustic alarms reduce porpoise mortality. Nature 388:525

Margavio AV, Forsyth C (1996) Caught in the net: the conflict between shrimpers and conservationists. In: Pratt JA (ed) Kenneth E. Montague series in oil and business history, 7. Texas A\&M University Press, College Station, TX

Margavio AV, Laska S, Mason J, Forsyth C (1993) Captives of conflict: the TEDs case. Soc Nat Resour 6:273-290

Maurstad A (2000) To fish or not to fish: small-scale fishing and changing regulations of the cod fishery in northern Norway. Hum Organ 59:37-47

McCay BJ, Jentoft S (1996) From the bottom up: participatory issues in fisheries management. Soc Nat Resour 9:237-250

McCay BJ, Apostle R, Creed CF (1998) Individual transferable quotas, comanagement, and community: lessons from Nova Scotia. Fisheries 23:20-23

McKechnie R (1996) Insiders and outsiders: identifying experts on home ground. In: Irwin A, Wynne B (eds) Misunderstanding science? Cambridge University Press, Cambridge, p 126-151

Melvin EF, Parrish JK, Conquest LL (1999) Novel tools to reduce seabird bycatch in coastal gillnet fisheries. Conserv Biol 13:1386-1397

Moberg M, Dyer CL (1994) Conservation and forced innovation: responses to turtle excluder devices among Gulf of Mexico shrimpers. Hum Organ 53:160-166

National Research Council (1990) Decline of the sea turtles: causes and prevention. National Academy Press, Washington, DC

> Nielsen JR, Vedsmand T (1999) User participation and institutional change in fisheries management: a viable alternative to the failures of 'top-down' driven control? Ocean Coast Manag 42:19-37

Pauly D, Christensen V, Guenette S, Pitcher TJ and others (2002) Towards sustainability in world fisheries. Nature 418:689-695

Pinkerton E (ed) (1989) Co-operative management of local fisheries: new directions for improved management and community development. University of British Columbia Press, Vancouver

Pretty JN (1995) The many interpretations of participation. Focus 16:4-5

Robbins P (2004) Political ecology. Blackwell, Malden, MA

Robins JB, Campbell MJ, McGilvray JG (1999) Reducing prawn-trawl bycatch in Australia: an overview and an example from Queensland. Mar Fish Rev 61:46-55

Santora C (2003) Management of turtle bycatch: Can endangered species be protected while minimizing socioeconomic impacts? Coast Manag 31:423-434

Silver JJ, Campbell LM (2005) Participation in fisheries research: obstacles and opportunities. Ocean Coast Manag 48:721-741

Singleton S (2000) Co-operation or capture? The paradox of co-management and community participation in natural 
resource management and environmental policy-making. Environ Polit 9:1-21

Spotila JR, Reina RD, Steyermark AC, Plotkin PT, Paladino FV (2000) Pacific leatherback turtles face extinction. Nature 405:529-530

St. Martin K (2001) Making space for community resource management in fisheries. Ann Assoc Am Geogr 91:122-142

St. Martin K (2005) Disrupting enclosure in New England fisheries. Capital Nat Soc 16(1):63-80

Tucker AD, Robins JB, McPhee DP (1997) Adopting turtle excluder devices in Australia and the United States: What are the differences in technology transfer, promotion, and acceptance? Coast Manag 25:405-421

Watson J (2007) Reconciling fisheries with conservation through programs to develop improved fishing technologies in the United States In: Kennelly SJ (ed) By-catch reduction in the world's fisheries. Springer Netherlands, Dordrecht, p 23-36

Editorial responsibility: David Agnew,

London, UK
Watson JW, Kerstetter DW (2006) Pelagic longline fishing gear: a brief history and review of research efforts to improve selectivity. Mar Technol Soc J 40:6-11

Western D, Wright MA (1994) The background to community-based conservation. In: Western D, Wright MA (eds) Natural connections: perspectives in community-based conservation. Island Press, Washington, DC, p 1-12

Wilson DC, McCay BJ (1998) How the participants talk about 'participation' in Mid-Atlantic fisheries management. Ocean Coast Manag 41:41-61

Worm B, Barbier EB, Beaumont N, Duffy JE and others (2006) Impacts of biodiversity loss on ocean ecosystem services. Science 314:787-790

Wynne B (1996) Misunderstood misunderstandings: social identities and public uptake of science. In: Irwin A, Wynne B (eds) Misunderstanding science? Cambridge University Press, Cambridge, p 19-46

Submitted: July 3, 2008; Accepted: November 14, 2008

Proofs received from author(s): December 8, 2008 